\title{
IMPLEMENTASI TEOREMA COLLAGE UNTUK MENDESAIN SISTEM FUNGSI ITERASI (SFI): STUDI AWAL MENDESAIN SFI MOTIF SONGKET LOMBOK
}

\author{
Afifurrahman \\ Program Studi Tadris Matematika FITK \\ Institut Agama Islam Negeri Mataram \\ Email: afifmath@yahoo.co.id
}

Abstrak: Geometri fraktal merupakan cabang matematika yang memfokuskan kajiannya pada objek-objek
fraktal. SFI yaitu teknik yang dapat digunakan untuk memodelkan objek fraktal. Tulisan ini memaparkan
bagaimana mengaplikasikan teorema Collage untuk mendesain SFI suatu himpunan $K \subset \mathbb{R}^{2}$ yang memiliki
sifat self-similarity. Mendesain SFI suatu himpunan $K \subset \mathbb{R}^{2}$ berarti mencari sejumlah berhingga pemetaan kontraktif berupa transformasi affine:

$$
w_{n}\left(\begin{array}{l}
x \\
y
\end{array}\right)=\left(\begin{array}{ll}
a_{n} & b_{n} \\
c_{n} & d_{n}
\end{array}\right)\left(\begin{array}{l}
x \\
y
\end{array}\right)+\left(\begin{array}{c}
e_{n} \\
f_{n}
\end{array}\right)
$$

dengan $a_{n}, b_{n}, c_{n}, d_{n}, e_{n}, f_{n} \in \mathbb{R}$ sedemikian sehingga $K^{\prime}=w_{n}(K)$ untuk $n=1,2, \ldots, N$. Keenam parameter pada persamaan di atas disebut sebagai kode SFI. Penelitian ini bertujuan untuk merancang suatu algoritma berdasarkan ide dari teorema Collage dalam menentukan kode SFI yang akan digunakan untuk memvisualisasikan atraktor dari objek fraktal menggunakan bahasa pemrograman. Algoritma yang telah disusun selanjutnya diterapkan untuk memperoleh SFI motif songket Lombok dan diperoleh hasil sebagai berikut:

$\left\{\left(\begin{array}{cc}0.84 & 0 \\ -0.02 & 0.8385\end{array}\right)\left(\begin{array}{l}x \\ y\end{array}\right)+\left(\begin{array}{c}0.08 \\ 0.1715\end{array}\right),\left(\begin{array}{cc}0.2 & -0.1538 \\ 0.04 & 0.4\end{array}\right)\left(\begin{array}{l}x \\ y\end{array}\right)+\left(\begin{array}{c}0.59 \\ -0.07\end{array}\right),\left(\begin{array}{cc}0.2 & 0.1231 \\ -0.04 & 0.4\end{array}\right)\left(\begin{array}{l}x \\ y\end{array}\right)+\left(\begin{array}{c}0.39 \\ -0.03\end{array}\right)\right\}$ dengan

faktor kontraktivitas $s=0.70434$.

Kata Kunci: Teorema Collage; Sifat Self-Similarity; Transformasi Affine; Algoritma; SFI; Atraktor.

Abstract: Fractal geometry is the branch of mathematics that focus its studies on fractals. Iterated Function Systems (IFS) acts as a technique to generate fractal models. This article presents how to implement the Collage Theorem to design IFS of $K \subset \mathbb{R}^{2}$ which hold self-similarity property. Designing IFS of $K \subset \mathbb{R}^{2}$ means that finding the finite contractive mapping i.e. affine transformation:

$$
w_{n}\left(\begin{array}{l}
x \\
y
\end{array}\right)=\left(\begin{array}{ll}
a_{n} & b_{n} \\
c_{n} & d_{n}
\end{array}\right)\left(\begin{array}{l}
x \\
y
\end{array}\right)+\left(\begin{array}{l}
e_{n} \\
f_{n}
\end{array}\right)
$$

where $a_{n}, b_{n}, c_{n}, d_{n}, e_{n}, f_{n} \in \mathbb{R}$ such that $K^{\prime}=w_{n}(K)$ for $n=1,2, \ldots, N$. The six parameters on the equation above are called IFS codes. The aim of the study is constructing the algorithm based on the Collage theorem to determine the IFS codes which are used to visualize the attractor of the fractal objects through programming language. The Algorithm is implemented to obtain the IFS of Songket's texture of Lombok and the result is given below:

$\left\{\left(\begin{array}{cc}0.84 & 0 \\ -0.02 & 0.8385\end{array}\right)\left(\begin{array}{l}x \\ y\end{array}\right)+\left(\begin{array}{c}0.08 \\ 0.1715\end{array}\right),\left(\begin{array}{cc}0.2 & -0.1538 \\ 0.04 & 0.4\end{array}\right)\left(\begin{array}{l}x \\ y\end{array}\right)+\left(\begin{array}{c}0.59 \\ -0.07\end{array}\right),\left(\begin{array}{cc}0.2 & 0.1231 \\ -0.04 & 0.4\end{array}\right)\left(\begin{array}{l}x \\ y\end{array}\right)+\left(\begin{array}{c}0.39 \\ -0.03\end{array}\right)\right\}$ with $\quad a$ contractivity factor $s=0.70434$.

Keywords: Collage Theorem; Self-Similarity; Affine Transformation; Algorithm; IFS; Attractor.

\section{PENDAHULUAN}

Suatu objek memiliki sifat self-similarity apabila bagian-bagiannya memiliki bentuk yang serupa dengan keseluruhan objek tersebut. Ankit Garg dkk menyatakan bahwa sifat self-similarity merupakan sifat utama pada objek-objek fraktal [1]. Himpunan Mandelbrot merupakan salah satu contoh terkenal pada bidang geometri fraktal yang memberikan ilustrasi terhadap sifat tersebut.

Istilah fraktal berasal dari bahasa latin fractus yang berarti pecah-pecah atau tidak beraturan dan istilah tersebut diberikan pertama kali oleh Benoit Mandelbrot [3]. Objek-objek fraktal banyak ditemukan di alam, seperti pada dedaunan, awan, pegunungan, bentuk galaksi, garis pantai, struktur tata bahasa manusia [2], dan lain sebagainya. Selain himpunan mandelbrot pada Gambar 1 terdapat juga beberapa objek fraktal yang sangat populer dan menjadi kajian dalam bidang matematika hingga saat ini, antara lain: the koch curve ditemukan oleh Helge Von Koch [4] dan sierpinski triangle yang didesain oleh Waclaw Sierpinski [5]. Hampir seluruh objek fraktal tidak dapat dimodelkan menggunakan bentuk-bentuk geometri klasik, seperti: segitiga, segiempat, dan lingkaran. Oleh karena itu, dibutuhkan pendekatan 
yang berbeda dalam merepresentasikan objek-objek tersebut.
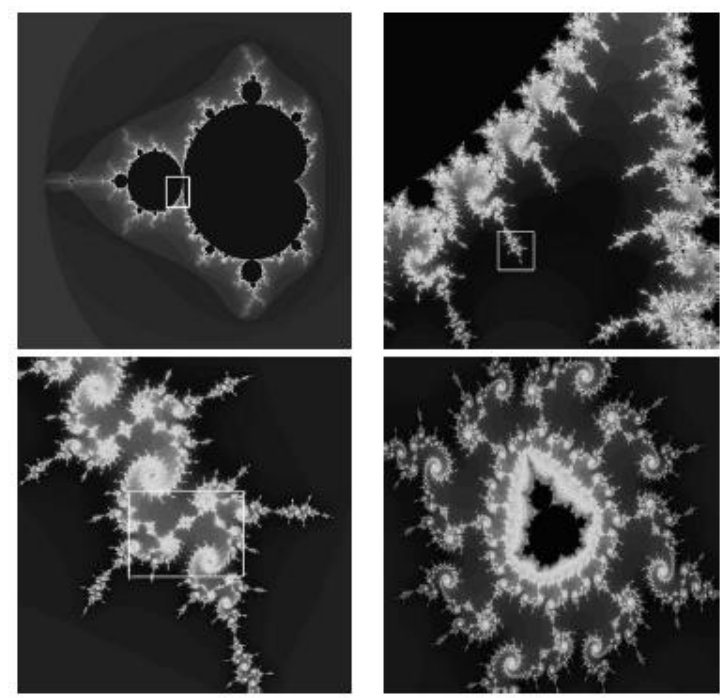

Gambar 1. Himpunan Mandelbrot untuk berbagai skala [2]

Sistem Fungsi Iterasi (SFI) merupakan teknik yang dapat digunakan untuk mengkonstruksi model-model fraktal. Menurut Barnsley, SFI dipandang sebagai inti geometri fraktal [6]. Sebagai contoh, SFI sierpinski triangle pada Gambar 2 diberikan oleh himpunan pemetaan kontraktif:

$$
\begin{gathered}
\left\{\left(\begin{array}{cc}
0.5 & 0 \\
0 & 0.5
\end{array}\right)\left(\begin{array}{l}
x \\
y
\end{array}\right)+\left(\begin{array}{l}
1 \\
1
\end{array}\right),\left(\begin{array}{cc}
0.5 & 0 \\
0 & 0.5
\end{array}\right)\left(\begin{array}{l}
x \\
y
\end{array}\right)+\right. \\
\left.\left(\begin{array}{c}
1 \\
50
\end{array}\right),\left(\begin{array}{cc}
0.5 & 0 \\
0 & 0.5
\end{array}\right)\left(\begin{array}{l}
x \\
y
\end{array}\right)+\left(\begin{array}{l}
50 \\
50
\end{array}\right)\right\} .
\end{gathered}
$$

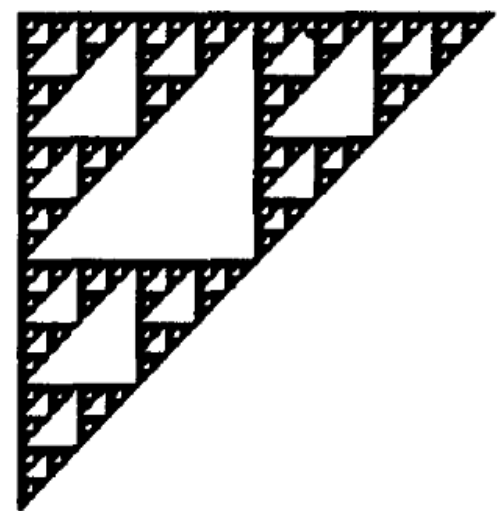

\section{Gambar 2. Atraktor Sierpinski triangle [7]}

Secara matematis SFI didefinisikan sebagai himpunan hingga pemetaan kontraktif pada ruang metrik lengkap $(X, d)$. Notasinya yaitu:

$$
\left\{w_{1}, w_{2}, \ldots, w_{N}\right\}
$$

dengan $w_{n}: X \rightarrow X$ untuk $n=1,2, \ldots, N$. Andaikan diberikan suatu himpunan $K \subset \mathbb{R}^{2}$ yang akan didesain SFI-nya, berarti akan dicari himpunan hingga pemetaan kontraktif pada ruang metrik lengkap $\left(\mathbb{R}^{2}, d\right)$ berbentuk:

$$
w_{n}\left(\begin{array}{l}
x \\
y
\end{array}\right)=\left(\begin{array}{ll}
a_{n} & b_{n} \\
c_{n} & d_{n}
\end{array}\right)\left(\begin{array}{l}
x \\
y
\end{array}\right)+\left(\begin{array}{c}
e_{n} \\
f_{n}
\end{array}\right)
$$

sedemikian sehingga $K^{\prime}=w_{n}(K)$ untuk $n=$ $1,2, \ldots, N$. Persamaan (1.1) disebut sebagai transformasi Affine dimensi-2 dengan $a_{n}, b_{n}, c_{n}, d_{n}$, $e_{n}$, dan $f_{n}$ adalah kode-kode SFI.

Dalam beberapa literatur, peneliti belum menemukan suatu algoritma untuk mendesain SFI objek-objek fraktal. Pada penelitian ini, yang dimaksud dengan algoritma yaitu langkah-langkah logis dan sistematis untuk menentukan kode-kode SFI pada persamaan (1.1). Algoritma tersebut dipandang perlu karena pembaca dapat mengubah cara perhitungan manual kode-kode SFI ke sistem komputerisasi menggunakan bahasa pemrograman. Tentunya, kalkulasi secara digital akan mempermudah pembaca dalam mendesain SFI serta menghemat konsumsi waktu dibandingkan dengan perhitungan secara manual. Fokus penelitian ini yaitu menyusun algoritma untuk mendesain SFI mengacu pada teorema Collage. Barnsley mengemukakan bahwa teorema Collage dapat membantu pembaca dalam mendesain SFI [7].

Teorema Collage menyatakan jika jarak himpunan $L$ dengan $W(L)=\bigcup_{n=1}^{N} w_{n}(L)$ tersebut lebih kecil dari nilai $\varepsilon \geq 0$ akan berakibat jarak $L$ dengan atraktor $A$ semakin kecil. Maksudnya yaitu ketika SFI ditemukan lalu pada $L$ dikenakan pemetaan $W$, maka akan diperoleh objek yang mirip persis dengan objek sebenarnya setelah pemetaan $W$ diiterasikan sebanyak $n$ kali. Teorema tersebut memaparkan tentang bagaimana memperoleh SFI sedemikian sehingga atraktor $A$ sama persis dengan objek sebenarnya. Kemiripan atraktor tidak berarti harus "sama dengan" objek yang didesain SFI-nya, sebab pada hipotesa diberikan syarat awal berupa nilai $\varepsilon$ yang mengindikasikan adanya error antara atraktor dengan objek sebenarnya. Ini didasarkan pada fakta bahwa, aproksimasi akan selalu menghasilkan nilai sisaan (error).

Echols \& Shadily mengartikan Collage sebagai susunan benda-benda dengan potongan kertas dan sebagainya yang ditempelkan pada bidang datar dan merupakan kesatuan karya seni [8]. Sesuai dengan arti istilah Collage tersebut, ide utama yang teorema tersebut yaitu menemukan sejumlah berhingga objek untuk menutupi himpunan $K \subset \mathbb{R}^{2}$. Objek-objek tersebut haruslah sebangun dan dapat berotasi, berefleksi, berkontraksi, dan bertranslasi [9]. Objek yang digunakan pada penelitian ini yaitu poligon karena dapat mempermudah peneliti dalam mengkonstruksi algoritma yang diinginkan. 
Penelitian ini terinspirasi oleh studi yang dilakukan oleh Simon D. Levy [2]. Ia menerapkan teorema Collage untuk memodelkan struktur kalimat dan tata bahasa manusia berdasarkan asumsi bahwa struktur dan tata bahasa tersebut mengikuti pola fraktal. Atas dasar itu, tulisan ini berupaya memaparkan bagaimana mendesain SFI objek-objek fraktal di $\mathbb{R}^{2}$ yang akan diimplementasikan pada motif songket Lombok dengan bantuan teorema Collage.

\section{METODE PENELITIAN}

Ditinjau dari tujuannya maka penelitian ini dapat dikategorikan sebagai penelitian terapan (applied research). Menurut Sugiyono [10] penelitian terapan adalah penelitian yang bertujuan untuk menerapkan atau menguji suatu teori dalam memecahkan masalah-masalah praktis. Berikut ini dijelaskan tahap-tahap yang ditempuh dalam penelitian ini.

\section{Studi Pustaka dan Diskusi}

Pada tahap ini, dilakukan studi serta telaah kepustakaan melalui buku-buku referensi, jurnal ilmiah dan internet tentang SFI, teorema Collage serta terminologi-terminologi dasar dari definisidefinisi maupun teorema-teorema terkait yang dapat membantu peneliti untuk memahami masalah serta tujuan yang ingin dicapai. Selain itu, dilakukan pula diskusi bersama dosen ahli tentang masalah yang akan diselesaikan.

\section{Merancang Algoritma}

Dari hasil telaah pustaka dan diskusi tersebut, dirancang suatu algoritma untuk mendesain SFI mengacu pada teorema Collage. Algoritma yang dihasilkan berupa urutan langkahlangkah logis dan sistematis untuk menentukan kode SFI pada persamaan transformasi affine (persamaan 1.1).

\section{Menguji Algoritma}

Pada tahap ini, algoritma yang diperoleh pada tahap 2 diuji untuk mendesain SFI objek penelitian berupa: bagian dari motif songket Lombok. Dari hasil pendesainan SFI tersebut, akan diperoleh kode SFI yang akan menjadi nilai input untuk proses visualisasi atraktor motif songket Lombok pada tahap 4.

\section{Visualisasi Atraktor}

Menggunakan algoritma iterasi random dengan implementasi bahasa pemrograman Delphi 7.0, atraktor dari objek penelitian: motif songket Lombok akan dikodekan dan divisualisasikan.

\section{Pengecekan Kondisi Atraktor}

Dari hasil pengkodean dan visualisasi pada tahap 4 akan ditarik kesimpulan apakah atraktor tersebut sudah baik atau belum. Baik atau belumnya atraktor yang dihasilkan tergantung ukuran kemiripan antara atraktor dengan objek sebenarnya. Ukuran kemiripan dihitung menggunakan metrik Hausdorff yang ditentukan oleh persamaan [7]:

$$
\begin{gathered}
h(A, B)=\operatorname{Max}\left\{\operatorname { M i n } \left\{d\left(\left(\begin{array}{l}
x_{1} \\
x_{2}
\end{array}\right),\left(\begin{array}{l}
y_{1} \\
y_{2}
\end{array}\right)\right):\left(\begin{array}{l}
x_{1} \\
x_{2}
\end{array}\right) \in\right.\right. \\
\left.\left.A,\left(\begin{array}{l}
y_{1} \\
y_{2}
\end{array}\right) \in B\right\}\right\}
\end{gathered}
$$

dengan

$d\left(\left(\begin{array}{l}x_{1} \\ x_{2}\end{array}\right),\left(\begin{array}{l}y_{1} \\ y_{2}\end{array}\right)\right)=\sqrt{\left(x_{1}-y_{1}\right)^{2}+\left(x_{2}-y_{2}\right)^{2}}$ untuk $A, B \in \mathcal{H}\left(\mathbb{R}^{2}\right)$.

Jika $h(A, B)$ konvergen ke nol, maka atraktor tersebut bisa dikatakan semakin baik dan penelitian berakhir dengan output berupa SFI motif songket Lombok. Sebaliknya, jika belum memenuhi, maka penelitian akan diulangi kembali dari tahap 3. Untuk lebih jelasnya, diagram alir dari tahap-tahap penelitian ini dapat dilihat pada Lampiran.

\section{HASIL DAN PEMBAHASAN}

\section{Algoritma untuk Mendesain SFI}

Berikut ini adalah algoritma yang dirancang untuk menentukan kode SFI suatu objek fraktal di $\mathbb{R}^{2}$ mengacu pada ide teorema Collage.

1. Pilih sebarang poligon $L_{0} \in \mathcal{H}\left(\mathbb{R}^{2}\right)$.

2. Inisialisasi nilai $n=1$.

3. Definisikan poligon $L_{n} \in \mathcal{H}\left(\mathbb{R}^{2}\right)$ yang sebangun dengan $L_{0}$ tetapi luasnya tidak lebih besar dari luas $L_{0}$.

4. Ambil $i$-titik verteks $L_{0}$, yaitu : $\left(\mathrm{x}_{1}, \mathrm{y}_{1}\right)$, $\left(\mathrm{x}_{2}, \mathrm{y}_{2}\right), \ldots,\left(\mathrm{x}_{i}, \mathrm{y}_{i}\right)$. Ambil juga $i$-titik verteks $L_{n}$, yaitu : $\left(\mathrm{x}_{1}, \mathrm{y}_{1}{ }^{\prime}\right),\left(\mathrm{x}_{2}, \mathrm{y}_{2}{ }^{\prime}\right), \ldots,\left(\mathrm{x}_{i}, \mathrm{y}_{i}{ }^{\prime}\right)$ untuk $i \geq$ 3 dengan $i \in \mathbb{N}$.

5. Substitusi titik-titik verteks yang dipilih pada langkah no.4 ke persamaan (1.3) dan (1.4).

$$
\begin{aligned}
& \left(\begin{array}{ccc}
x_{1} & y_{1} & 1 \\
x_{2} & y_{2} & 1 \\
\cdot & \cdot & \cdot \\
\cdot & \cdot & \cdot \\
\cdot & \cdot & \cdot \\
x_{i} & y_{i} & 1
\end{array}\right)\left(\begin{array}{l}
a \\
b \\
e
\end{array}\right)=\left(\begin{array}{l}
x_{1}{ }^{\prime} \\
x_{2} \\
\cdot \\
- \\
x_{i}{ }^{\prime}
\end{array}\right) \\
& \left(\begin{array}{ccc}
x_{1} & y_{1} & 1 \\
x_{2} & y_{2} & 1 \\
\cdot & \cdot & \cdot \\
\cdot & \cdot & \cdot \\
\cdot & \cdot & \cdot \\
x_{i} & y_{i} & 1
\end{array}\right)\left(\begin{array}{l}
c \\
d \\
f
\end{array}\right)=\left(\begin{array}{l}
y_{1}^{\prime} \\
y_{2} \\
\cdot \\
\cdot \\
\cdot \\
y_{i}^{\prime}
\end{array}\right)
\end{aligned}
$$

Selesaikan kedua persamaan tersebut untuk memperoleh nilai $a, b, c, d, e$ dan $f$

6. Tulis nilai $a_{n}=a, b_{n}=b, c_{n}=c, d_{n}=d, e_{n}=e$ $\operatorname{dan} f_{n}=f$. 
7. Ulangi kembali mulai langkah 3 untuk $n=n+$ 1 sampai $n=K$.

Keterangan: $K$ yaitu jumlah poligon $L$ yang diperlukan untuk menutupi objek fraktal.

Sebagaimana yang telah disebutkan pada bagian pendahuluan bahwa untuk mendesain SFI suatu objek fraktal dapat dilakukan dengan cara menutupi objek tersebut dengan sejumlah himpunan sebangun yang dapat dirotasikan, direfleksikan, dikontraksikan dan ditranslasikan. Gambar 3 mengilustrasikan bagaimana ide dari teorema Collage bekerja dalam mendesain SFI. Objek fraktal pada Gambar 3 ditutupi oleh segitiga $\mathrm{L}_{0}$ (berwarna merah) dan tiga segitiga yang sebangun $\left(\mathrm{L}_{1}, \mathrm{~L}_{2}\right.$, dan $\left.\mathrm{L}_{3}\right)$ dengan $\mathrm{L}_{0}$.

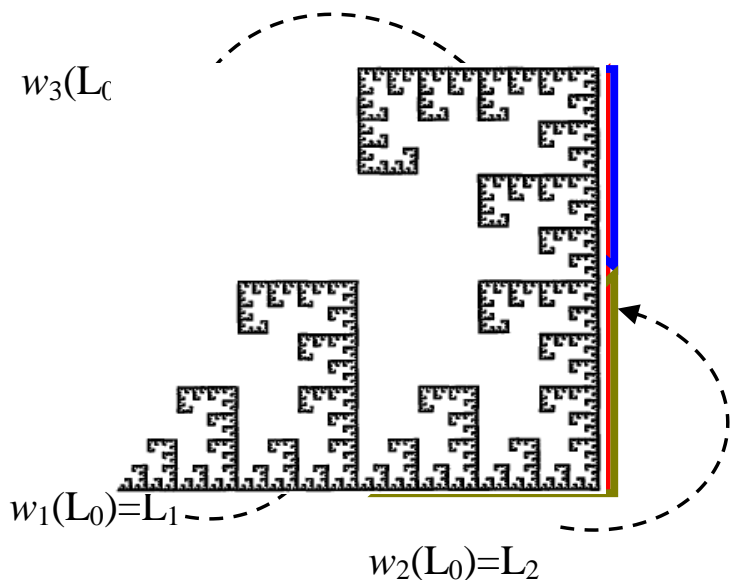

Gambar 3. Proses Pendesainan SFI

Himpunan yang digunakan untuk menutupi objek fraktal pada penelitian ini yaitu poligon, seperti: segitiga atau segiempat. Pemilihan poligon tersebut dilakukan karena daerah hasil (range) dari transformasi affine yang dikenakan pada poligon lebih jelas terlihat visualisasinya pada bidang Cartesius dibandingkan himpunan lainnya, seperti: titik, garis atau lingkaran. Selain itu, poligon dipilih karena dapat memudahkan peneliti untuk merancang Algoritma. Lebih jelasnya, pembaca dapat memperhatikan Gambar 4.

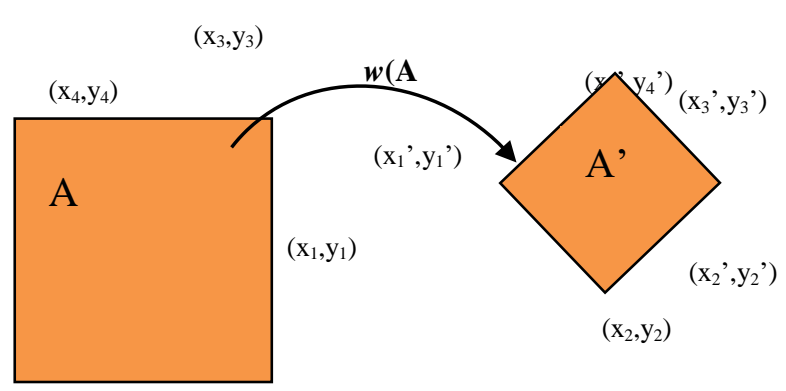

Gambar 4. Transformasi affine $w$ pada Poligon
Setiap titik pada poligon A dipetakan oleh $w$ sedemikian sehingga $w(\mathrm{~A})=\mathrm{A}^{\prime}$ '. Titik-titik verteks A dipetakan oleh $w$ ke titik-titik verteks A' yang bersesuaian sedemikian sehingga,

$$
\begin{gathered}
\left(\begin{array}{l}
x_{1}{ }^{\prime} \\
y_{1}{ }^{\prime}
\end{array}\right)=\left(\begin{array}{ll}
a & b \\
c & d
\end{array}\right)\left(\begin{array}{l}
x_{1} \\
y_{1}
\end{array}\right)+\left(\begin{array}{l}
e \\
f
\end{array}\right) \Leftrightarrow \\
a x_{1}+b y_{1}+e=x_{1}{ }^{\prime} \\
c x_{1}+d y_{1}+f=y_{1}{ }^{\prime} \\
\left(\begin{array}{ll}
1.5) \\
x_{2}{ }^{\prime} \\
y_{2}{ }^{\prime}
\end{array}\right)=\left(\begin{array}{ll}
a & b \\
c & d
\end{array}\right)\left(\begin{array}{l}
x_{2} \\
y_{2}
\end{array}\right)+\left(\begin{array}{l}
e \\
f
\end{array}\right) \Leftrightarrow \\
a x_{2}+b y_{2}+e=x_{2}{ }^{\prime} \\
c x_{2}+d y_{2}+f=y_{2}{ }^{\prime} \\
\left(\begin{array}{l}
x_{3}{ }^{\prime} \\
y_{3}^{\prime}
\end{array}\right)=\left(\begin{array}{ll}
a & b \\
c & d
\end{array}\right)\left(\begin{array}{l}
x_{3} \\
y_{3}
\end{array}\right)+\left(\begin{array}{l}
e \\
f
\end{array}\right) \Leftrightarrow \\
a x_{3}+b y_{3}+e=x_{3}{ }^{\prime} \\
c x_{3}+d y_{3}+f=y_{3}{ }^{\prime} \\
\left(\begin{array}{l}
x_{4}{ }^{\prime} \\
y_{4}{ }^{\prime}
\end{array}\right)=\left(\begin{array}{ll}
a & b \\
c & d
\end{array}\right)\left(\begin{array}{l}
x_{4} \\
y_{4}
\end{array}\right)+\left(\begin{array}{l}
e \\
f
\end{array}\right) \Leftrightarrow \\
a x_{4}+b y_{4}+e=x_{4}{ }^{\prime} \\
c x_{4}+d y_{4}+f=y_{4}{ }^{\prime}
\end{gathered}
$$

Persamaan-persamaan linear (1.5), (1.6), (1.7) dan (1.8) dapat ditulis kembali dalam bentuk persamaan matriks $\mathrm{Ax}=\mathrm{b}$ yang diberikan oleh persamaan (1.9) dan (1.10). Jika poligon yang dipilih mempunyai $i$-titik verteks maka persamaan (1.9) dan (1.10) masing-masing dapat diperumum menjadi persamaan (1.3) dan (1.4).

$$
\left(\begin{array}{lll}
x_{1} & y_{1} & 1 \\
x_{2} & y_{2} & 1 \\
x_{3} & y_{3} & 1 \\
x_{4} & y_{4} & 1
\end{array}\right)\left(\begin{array}{l}
a \\
b \\
e
\end{array}\right)=\left(\begin{array}{l}
x_{1}^{\prime} \\
x_{2}{ }^{\prime} \\
x_{3}^{\prime} \\
x_{4}^{\prime}
\end{array}\right)
$$

$$
\left(\begin{array}{lll}
x_{1} & y_{1} & 1 \\
x_{2} & y_{2} & 1 \\
x_{3} & y_{3} & 1 \\
x_{4} & y_{4} & 1
\end{array}\right)\left(\begin{array}{l}
c \\
d \\
f
\end{array}\right)=\left(\begin{array}{l}
y_{1}^{\prime} \\
y_{2}^{\prime} \\
y_{3}^{\prime} \\
y_{4}^{\prime}
\end{array}\right)
$$

(1.10)

\section{SFI Objek Fraktal pada Gambar 3}

SFI objek fraktal pada Gambar 3 akan didesain menggunakan Algoritma yang telah disusun. Dipilih titik verteks $\mathrm{L}_{0}$ : $(0,0),(1,0),(1,1)$; titik verteks $\mathrm{L}_{1}:(0,0),(0.5,0),(0.5,0.5)$; titik verteks $\mathrm{L}_{2}$ : $\quad(0.5,0),(1,0),(1,0.5)$; titik verteks $\mathrm{L}_{3}$ : $(1,0.5),(1,1),(0.5,1)$. Penentuan titik-titik verteks pada penelitian ini menggunakan bantuan milimeter 
block. Selanjutnya, titik-titik verteks diinput ke persamaan (1.2) dan (1.3), sehingga diperoleh kode

Tabel 1. Kode SFI

\begin{tabular}{|c|c|c|c|c|c|c|}
\hline$n$ & $a_{n}$ & $b_{n}$ & $c_{n}$ & $d_{n}$ & $e_{n}$ & $f_{n}$ \\
\hline 1 & 0.5 & 0 & 0 & 0.5 & 0 & 0 \\
\hline 2 & 0.5 & 0 & 0 & 0.5 & 0.5 & 0 \\
\hline 3 & 0 & -0.5 & 0.5 & 0 & 1 & 0.5 \\
\hline
\end{tabular}

Berdasarkan kode SFI yang disajikan pada Tabel 1, SFI objek fraktal Gambar 3 diberikan oleh himpunan hingga pemetaan kontraktif:

$$
\left\{\left(\begin{array}{cc}
0.5 & 0 \\
0 & 0.5
\end{array}\right)\left(\begin{array}{l}
x \\
y
\end{array}\right)+\left(\begin{array}{l}
0 \\
0
\end{array}\right),\left(\begin{array}{cc}
0.5 & 0 \\
0 & 0.5
\end{array}\right)\left(\begin{array}{l}
x \\
y
\end{array}\right)+\left(\begin{array}{c}
0.5 \\
0
\end{array}\right),\left(\begin{array}{cc}
0 & -0.5 \\
0.5 & 0
\end{array}\right)\left(\begin{array}{l}
x \\
y
\end{array}\right)+\left(\begin{array}{c}
1 \\
0.5
\end{array}\right)\right\}
$$

dengan faktor kontraktivitas $S=0.25$. Atraktor dari SFI objek fraktal pada Gambar 3 ditampilkan pada Gambar 5. Kemiripan atraktor dengan objek fraktal dapat dihitung menggunakan persamaan (1.2) sebagaimana diilustrasikan oleh prosedur berikut ini.

$$
\begin{aligned}
h\left(L_{0}, \bigcup_{n=1}^{3} w_{n}\left(L_{0}\right)\right) & \left.=h\left(\left\{\left(\begin{array}{l}
0 \\
0
\end{array}\right),\left(\begin{array}{l}
1 \\
0
\end{array}\right),\left(\begin{array}{l}
1 \\
1
\end{array}\right)\right\},\left\{\left(\begin{array}{l}
0 \\
0
\end{array}\right),\left(\begin{array}{c}
0.5 \\
0
\end{array}\right),\left(\begin{array}{l}
0.5 \\
0.5
\end{array}\right)\right\} \bigcup\left\{\left(\begin{array}{c}
0.5 \\
0
\end{array}\right),\left(\begin{array}{l}
1 \\
0
\end{array}\right),\left(\begin{array}{c}
1 \\
0.5
\end{array}\right)\right\} \bigcup\left(\begin{array}{c}
1 \\
0.5
\end{array}\right),\left(\begin{array}{l}
1 \\
1
\end{array}\right),\left(\begin{array}{c}
0.5 \\
1
\end{array}\right)\right\}\right) \\
& =h\left(\left\{\left(\begin{array}{l}
0 \\
0
\end{array}\right),\left(\begin{array}{l}
1 \\
0
\end{array}\right),\left(\begin{array}{l}
1 \\
1
\end{array}\right)\right\},\left\{\left(\begin{array}{l}
0 \\
0
\end{array}\right),\left(\begin{array}{c}
0.5 \\
0
\end{array}\right),\left(\begin{array}{l}
0.5 \\
0.5
\end{array}\right),\left(\begin{array}{l}
1 \\
0
\end{array}\right),\left(\begin{array}{c}
1 \\
0.5
\end{array}\right),\left(\begin{array}{l}
1 \\
1
\end{array}\right),\left(\begin{array}{c}
0.5 \\
1
\end{array}\right)\right\}\right) \\
& =0
\end{aligned}
$$

Pilih $\varepsilon=0.01 \geq 0$ sedemikian sehingga

$$
h\left(\left\{\left(\begin{array}{l}
0 \\
0
\end{array}\right),\left(\begin{array}{l}
1 \\
0
\end{array}\right),\left(\begin{array}{l}
1 \\
1
\end{array}\right)\right\}, A\right) \leq \frac{0.01}{1-0.25}=0.013<0.014
$$

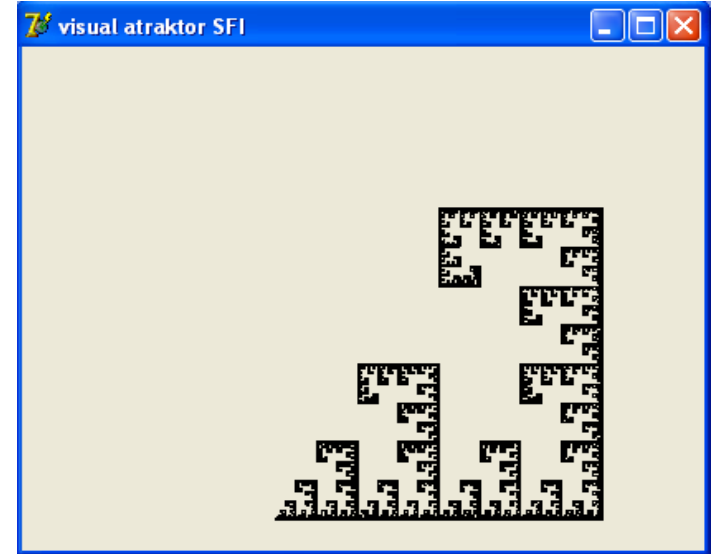

Gambar 5. Atraktor SFI Objek Fraktal pada Gambar 3

\section{SFI Motif Songket Lombok}

Gambar 6 menampilkan motif songket Lombok yang dijadikan sebagai objek pada penelitian ini. Prosedur serupa yang digunakan untuk mendesain SFI objek fraktal pada Gambar 3 juga akan diimplementasikan pada bagian motif songket yang dibatasi oleh persegi panjang berwarna merah.

Motif songket tersebut ditutupi menggunakan empat poligon $\mathrm{L}_{0}, \mathrm{~L}_{1}, \mathrm{~L}_{2}, \mathrm{~L}_{3}$ yang sebangun. $\mathrm{L}_{0}$ ditandai oleh poligon berwarna merah, $w_{1}\left(\mathrm{~L}_{0}\right)=\mathrm{L}_{1}$ ditandai oleh poligon berwarna kuning, $w_{2}\left(\mathrm{~L}_{0}\right)=\mathrm{L}_{2}$ ditandai oleh poligon berwarna ungu, dan $w_{3}\left(\mathrm{~L}_{0}\right)=\mathrm{L}_{3}$ ditandai oleh poligon berwarna hijau.

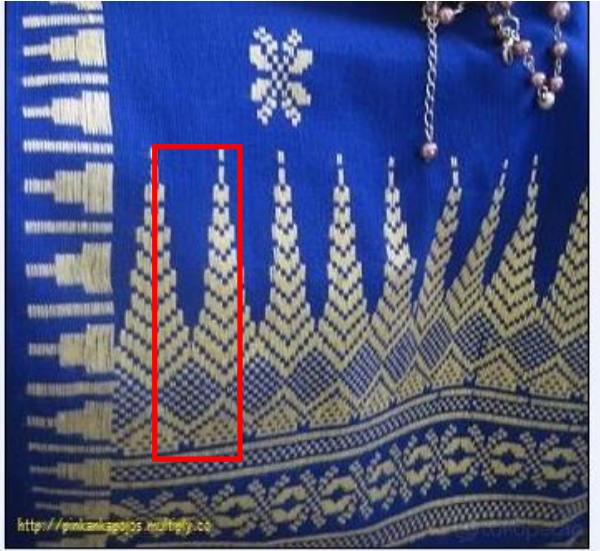

Gambar 6. Motif Songket Lombok (Motif Pinggiran)

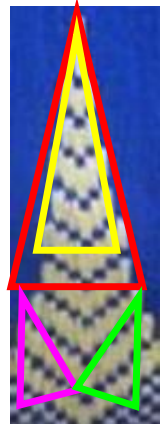

Gambar 7. Proses Pendesainan SFI Motif Pinggiran

Dipilih titik verteks $\mathrm{L}_{0}: \quad(0.25,0.35)$, $(0.75,0.35),(0.5,1)$; titik verteks $\mathrm{L}_{1}:(0.29,0.45)$, $(0.71,0.45),(0.5,1)$; titik verteks $\mathrm{L}_{2}:(0.4,0.08)$, $(0.5,0.1),(0.35,0.35)$; titik verteks $\mathrm{L}_{3}:(0.5,0.1)$, 
$(0.6,0.08),(0.63,0.35)$ dan diperoleh kode SFI pada

Tabel 2.

Tabel 2. Kode SFI Motif Pinggiran

\begin{tabular}{|c|c|c|c|c|c|c|}
\hline$n$ & $a_{n}$ & $b_{n}$ & $c_{n}$ & $d_{n}$ & $e_{n}$ & $f_{n}$ \\
\hline 1 & 0.84 & 0 & -0.02 & 0.8385 & 0.08 & 0.1715 \\
\hline 2 & 0.2 & -0.1538 & 0.04 & 0.4 & 0.4038 & -0.07 \\
\hline 3 & 0.2 & 0.1231 & -0.04 & 0.4 & 0.4069 & -0.03 \\
\hline
\end{tabular}

Berdasarkan data pada Tabel 2, SFI Motif Pinggiran diberikan oleh himpunan pemetaan kontraktif: $\left\{\left(\begin{array}{cc}0.84 & 0 \\ -0.02 & 0.8385\end{array}\right)\left(\begin{array}{l}x \\ y\end{array}\right)+\left(\begin{array}{c}0.08 \\ 0.1715\end{array}\right),\left(\begin{array}{cc}0.2 & -0.1538 \\ 0.04 & 0.4\end{array}\right)\left(\begin{array}{l}x \\ y\end{array}\right)+\left(\begin{array}{c}0.4038 \\ -0.07\end{array}\right),\left(\begin{array}{cc}0.2 & 0.1231 \\ -0.04 & 0.4\end{array}\right)\left(\begin{array}{l}x \\ y\end{array}\right)+\left(\begin{array}{c}0.4069 \\ -0.03\end{array}\right)\right\}$ dengan faktor kontraktivitas $s=0.70434$. Atraktor dari SFI Motif Pinggiran pada Gambar 7 ditampilkan pada Gambar 8. Kemiripan atraktor dengan Motif Pinggiran dihitung sebagai berikut.

$$
h\left(L_{0}, \bigcup_{n=1}^{3} w_{n}\left(L_{0}\right)\right)=h\left(\left\{\left(\begin{array}{l}
0.25 \\
0.35
\end{array}\right),\left(\begin{array}{c}
0.75 \\
0.35
\end{array}\right),\left(\begin{array}{c}
0.5 \\
1
\end{array}\right)\right\},\left\{\left(\begin{array}{l}
0.29 \\
0.45
\end{array}\right),\left(\begin{array}{l}
0.71 \\
0.34
\end{array}\right),\left(\begin{array}{c}
0.5 \\
1
\end{array}\right),\left(\begin{array}{c}
0.4 \\
0.08
\end{array}\right),\left(\begin{array}{l}
0.5 \\
0.1
\end{array}\right),\left(\begin{array}{l}
0.35 \\
0.35
\end{array}\right),\left(\begin{array}{c}
0.6 \\
0.08
\end{array}\right),\left(\begin{array}{l}
0.63 \\
0.35
\end{array}\right)\right\}\right)=0.12
$$

Pilih $\varepsilon=0.13 \geq 0.12$ sedemikian sehingga

$$
h\left(\left\{\left(\begin{array}{l}
0.25 \\
0.35
\end{array}\right),\left(\begin{array}{c}
0.75 \\
0.35
\end{array}\right),\left(\begin{array}{c}
0.5 \\
1
\end{array}\right)\right\}, A\right) \leq \frac{0.13}{1-0.70434}=0.29566<0.3
$$

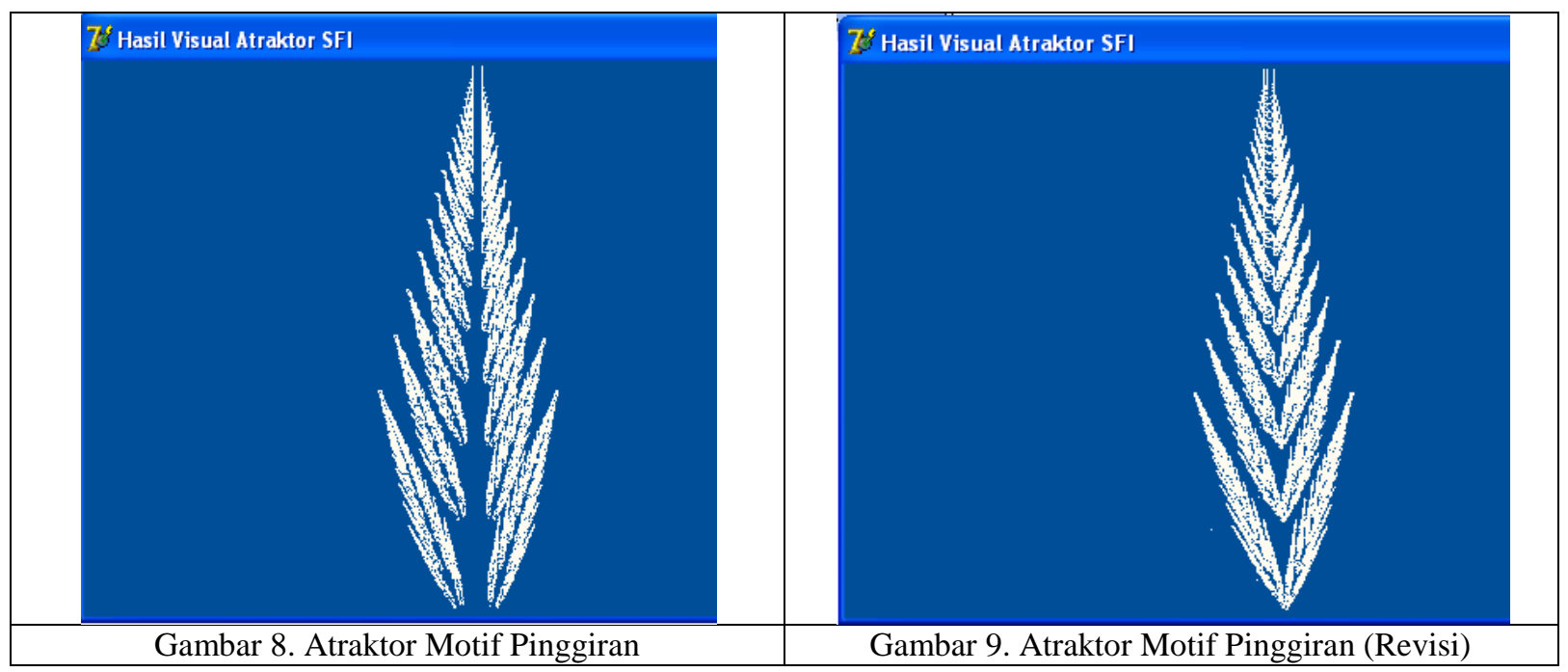

Dilakukan revisi terhadap Kode SFI Motif Pinggiran pada Tabel 2 untuk memperoleh atraktor yang lebih lebih mirip dengan objek sebenarnya. Dengan demikian, SFI Motif Pinggiran terbaru diberikan oleh himpunan pemetaan kontraktif:

$$
\left\{\left(\begin{array}{cc}
0.84 & 0 \\
-0.02 & 0.8385
\end{array}\right)\left(\begin{array}{l}
x \\
y
\end{array}\right)+\left(\begin{array}{c}
0.08 \\
0.1715
\end{array}\right),\left(\begin{array}{cc}
0.2 & -0.1538 \\
0.04 & 0.4
\end{array}\right)\left(\begin{array}{l}
x \\
y
\end{array}\right)+\left(\begin{array}{c}
0.59 \\
-0.07
\end{array}\right),\left(\begin{array}{cc}
0.2 & 0.1231 \\
-0.04 & 0.4
\end{array}\right)\left(\begin{array}{l}
x \\
y
\end{array}\right)+\left(\begin{array}{c}
0.39 \\
-0.03
\end{array}\right)\right\}
$$

dengan faktor kontraktivitas $s=0.70434$. Kemiripan atraktor pada Gambar 9 dengan Motif Pinggiran dapat dihitung menggunakan prosedur sebagaimana yang telah dicontohkan.

\section{DAFTAR PUSTAKA}

[1] Garg, A., dkk. 2014. A Review on Natural Phenomenon of Fractal Geometry. International Journal of Computer Applications, 86(4): 0975 - 8887.

[2] Levy, S.D. Neuro-Fractal Composition of Meaning: Toward a Collage Theorem for Language.

http://www.cs.stir.ac.uk/ 1ss/BICS2004/
CD/papers/1101.pdf, Diakses tgl. 2 November 2015.

[3] Falconer, K. 1997. Techniques in Fractal Geometry. John Wiley \& Sons, England.

[4] Narasimhan, A. The Koch Curve. https://home.iitm.ac.in/arunn/kochcurve.html, Diakses tgl. 4 November 2015. 
[5] Parsons, M. Sierpinski Triangle. http://jwilson.coe.uga.edu/emat6680/pars ons/mvp6690/essay1/sierpinski.html, Diakes tgl. 4 November 2015.

[6] Barnsley, M., Vince, A. 2013. Developments in fractal geometry. Bulletin of Mathematical Sciences, Vol.3: 299 348.

[7] Barnsley, M. 1988. Fractals Everywhere. Academic Press Inc., Boston.
[8] Echols, J., M., and Shadily, H. 1976. Kamus Inggris - Indonesia. PT Gramedia Pustaka Utama, Jakarta.

[9] Arnold, D. Iterated Function Systems. http://msemac.redwoods.edu/ darnold/ifs /index.htm, Diakses tgl. 3 November 2015.

[10] Sugiyono. 2011. Metode Penelitian Kuantitatif, Kualitatif dan $R \& D$. Alfabeta, Bandung. 